\title{
PENGARUH KEBIJAKAN MANAJEMEN MODAL KERJA TERHADAP PROFITABILITAS DAN NILAI PERUSAHAAN
}

\author{
Kurnia Contesa ${ }^{1)}$, Mega Mayasari ${ }^{2)}$ \\ 1) Jurusan Manajemen Bisnis, Politeknik Caltex Riau, Pekanbaru 28265, email: contesa.nia@gmail.com \\ 2) Jurusan Manajemen Bisnis, Politeknik Negeri Batam, Batam 29461, email: mega@polibatam.ac.id
}

\begin{abstract}
Abstrak - Kurangnya pengelolaan modal kerja pada perusahaan dapat menurunkan tingkat profitabilitas dan nilai perusahaan. Penelitian kebijakan modal kerja investasi agresif (AIP) dan pembiayaan agresif (AFP) bertujuan untuk menguji pengaruh profitabilitas dan nilai perusahaan. Sampel penelitian berjumlah 170 perusahaan manufaktur yang terdaftar pada Bursa Efek Indonesia (BEI) periode 2010 hingga 2014. Alat analisis yang digunakan adalah analisis regresi data panel dengan eviews 8.0 dengan metode kuantitatif. Hasil penelitian menunjukkan bahwa kebijakan investasi agresif (AIP) berpengaruh terhadap profitabilitas dan nilai perusahaan, sedangkan kebijakan pembiayaan agresif tidak berpengaruh terhadap profitabilitas dan nilai perusahaan. Penelitian ini hanya membahas mengenai kebijakan agresif pada pembiayaan dan investasi perusahaan. Untuk memperbaiki keterbatasan tersebut peneliti menyarankan kepada peneliti selanjutnya untuk memasukkan kebijakan agresif dan konservatif pada kebijakan pembiayaan dan investasi perusahaan. Penelitian ini menggunakan teori struktur modal, packing order theory dan manajemen modal kerja. Penelitian ini dapat membantu perusahaan dalam mengelola modal kerja dengan maksimal untuk meningkatkan profitabilitas dan nilai perusahaan melalui kegiatan investasi dan pembiayaan.
\end{abstract}

Kata Kunci : Kebijakan investasi agresif (AIP), kebijakan pembiayaan agresif (AFP), profitabilitas dan nilai perusahaan

\begin{abstract}
Lack of management working capital at the company can to reduced profitability and corporate value. Research aggressive policy of working capital investment (AIP) and the aggressive financing (AFP) aims to examine the effect of profitability and corporate value. These samples included 170 companies listed on the Indonesian Stock Exchange (BEI) in the period 2010 to 2014. The analysis tool used is a panel data regression analysis with eviews 8.0 with quantitative methods. The results showed that the aggressive investment policy (AIP) affect the profitability and value of the company, while the aggressive financing policy does not affect the profitability and value of the company. This study only discusses the aggressive policy to finance and investment companies. To fix the limitations researcher suggests to the next researchers to incorporate aggressive and conservative policies on financing and investment policy of the company. This study uses the theory of capital structure, order packing theory and working capital management. This research can help companies in managing working capital with up to improve the profitability and value of the company through investment and financing activities.
\end{abstract}

Keywords: aggressive investment policy (AIP), aggressive financing policies (AFP), the profitability and value of the company

\section{PENDAHULUAN}

Salah satu sarana ekonomi yang dikelola secara bersama untuk memaksimalkan laba dan nilai adalah perusahaan. Keberhasilan sebuah perusahaan dapat dilihat dari kemampuan manajemen dalam melihat kesempatan dimasa yang akan datang. Untuk mencapai tujuan perusahaan dibutuhkan sebuah manajemen yang baik pada modal kerja perusahaan. Manajemen modal kerja merupakan komponen yang langsung berpengaruh pada profitabilitas dan likuiditas perusahaan, untuk itu perusahaan perlu mengelola modal kerja agar jumlahnya tidak terlalu besar ataupun terlalu kecil (Rehman dan Nasr, 2007). Perusahaan dengan jumlah modal kerja yang terlalu kecil akan mengalami likuiditas yang disebabkan minimnya modal kerja dalam memenuhi kewajiban lancar yang telah jatuh tempo. Modal kerja yang terlalu besar akan menyebabkan dana menganggur yang dapat mengurangi laba.

Komponen manajemen modal kerja meliputi average collection period (ACP), inventory conversion period (ICP), average payment period (APP), dan cash conversion cycle (CCC). Penelitian sebelumnya yang dilakukan oleh Dong dan $\mathrm{Su}$ (2010), Mathuva (2010), Raheman dan Nasr (2007), Sen dan Oruc (2009) menunjukkan bahwa manajemen modal kerja yang diukur melalui cash conversion cycle, average collection period, dan inventory conversion period berpengaruh negatif terhadap profitabilitas perusahaan, sedangkan average payment period berpengaruh positif terhadap profitabilitas.

Penelitian Lazaridis dan Tryfonidis (2006) menemukan hasil yang berbeda, dimana adanya 
hubungan positif antara manajemen modal kerja yang diukur mealui cash conversion cycle dan profitabilitas perusahaan, hal ini diperkuat dengan penelitian yang dilakukan oleh Quayyum (2012), Akoto at al (2012) dan Qazi at al (2011).

Manajemen modal kerja juga dapat diukur melalui kebijakan pembiayaan dan investasi dengan sifat agresif maupun konservatif yang dapat menghasilkan tingkat profitabilitas dan risiko yang berbeda. Terkait dengan kebijakan manajemen modal kerja Horne dan Wachwicz dalam Nazir dan Afza (2009) menyebutkan bahwa kebijakan investasi yang agresif akan memiliki pengaruh positif terhadap profitabilitas perusahaan. Dengan kata lain, kebijakan pembiayaan yang agresif akan memiliki pengaruh negatif terhadap profitabilitas perusahaan. Hasil penelitia yang berbeda ditemukan oleh Vahid at al (2012) Penelitian ini menemukan bahwa kebijakan investasi agresif dan pembiayaan agresif memiliki dampak positif terhadap nilai dan profitabilitas perusahaan.

Posisi likuiditas perusahaan dapat dipertahankan melalui pinjaman jangka pendek serta sumber pendanaan alternatif lainya. Di Indonesia sendiri pinjaman jangka pendek serta pendanaan alternatif masih cukup sulit untuk diperoleh, sehingga perusahaan dituntut untuk dapat menemukan komposisi kebijakan pembiayaan dan investasi dengan sifat agresif ataupun konservatif yang paling tepat. Penelitian ini dirancang untuk membantu perusahaan dalam mengoptimalkan pembiayaan serta keputusan investasi untuk meningkatkan profitabilitas dan nilai perusahaan serta untuk membuktikan secara empiris penelitian terdahulu mengenai kebijakan manajemen modal kerja.

Permasalah yang akan diangkat dalam penelitian ini adalah: Apakah terdapat pengaruh kebijakan manajemen modal kerja investasi agresif (AIP) terhadap profitabilitas perusahaan, Apakah terdapat pengaruh kebijakan manajemen modal kerja pembiayaan agresif (AFP) terhadap profitabilitas perusahaan, Apakah terdapat pengaruh kebijakan manajemen modal kerja pembiayaan agresif (AIP) terhadap nilai perusahaan dan Apakah terdapat pengaruh kebijakan manajemen modal kerja pembiayaan agresif (AFP) terhadap nilai perusahaan.

Dengan tujuan untuk mendapatkan bukti secara empiris mengenai dampak dari kebijakan manajemen modal kerja investasi agresif terhadap profitabilitas perusahaan, dampak dari kebijakan manajemen modal kerja pembiayaan agresif terhadap profitabilitas perusahaan, untuk mengetahui dampak kebijakan manajemen modal kerja investasi agresif terhadap nilai perusahaan dan untuk mengetahui dampak kebijakan manajemen modal kerja pembiayaan agresif terhadap nilai perusahaan.

\section{LANDASAN TEORI}

\subsection{Kajian Teori}

\subsubsection{Teori Struktur Modal}

Teori struktur modal diasumsikan sebagai perubahan struktur modal yang berasal dari penerbitan obligasi dan pembelian kembali saham biasa atau penerbitan saham baru. Martono dan Harijito (2010) membagi struktur modal dalam tiga pendekatan, yaitu: Pendekatan laba operasi bersih (Net Operating Income Approach) dikemukakan oleh Sartono (2001). Pendekatan ini mengasumsikan bahwa investor memiliki reaksi yang berbeda terhadap penggunaan hutang. Artinya apabila perusahaan menggunakan hutang yang lebih besar, maka pemilik saham akan memperoleh laba yang semakin kecil.

Pendekatan tradisional yang diasumsikan adalah terjadi perubahan struktur modal yang optimal dan peningkatan nilai total perusahaan melalui penggunaan financial leverage. Pendekatan ini akan menghasilkan struktur modal yang optimal yaitu struktur modal yang memberikan biaya modal keseluruhan yang terendah dan memberikan harga saham yang tertinggi. Pendekatan Modigliani dan Miller (MM Approach) menerangkan pembagian struktur modal pada hutang dan modal sendiri untuk melindungi nilai investasi, yang disebabkan karena nilai investasi dari total perusahaan tergantung pada keuntungan dan resiko sehingga nilai perusahaan tidak berubah walaupun struktur modalnya berubah.

\subsubsection{Teori Paking Order}

Perusahaan dengan tingkat profitabilitas yang tinggi akan memiliki tingkat hutang yang rendah, dikarenakan perusahaan yang profitabilitasnya tinggi memiliki sumber dana internal yang berlimpah (Sugiarto, 2009). Myers dan Majluf (1984) berpendapat bahwa ekuitas merupakan sarana yang kurang disukai dalam meningkatkan modal perusahaan, hal ini disebabkan karena investor mengira manajer menilai perusahaan terlalu tinggi dan manajer mengambil keuntungan dari over-valuation saat ekuitas baru dikeluarkan. Pecking Order Theory dapat menjelaskan mengapa perusahaan yang mempunyai tingkat keuntungan yang lebih tinggi mempunyai tingkat hutang yang lebih kecil (Ferdiansyah dan Isnurhadi, 2013).

\subsubsection{Manajemen Modal Kerja}

Perusahaan melakukan pembiayaan dan investasi dalam mengatur dan memutar modal, hal tersebut dapat mencerminkan kebijakan yang dilakukan oleh perusahaan dalam melaksanakan manajemen modal kerja. Manajemen modal kerja bertujuan untuk mengelola aktiva lancar dan hutang 
lancar sehingga memperoleh modal kerja neto yang layak dan menjamin tingkat likuiditas perusahaan (Martono dan Harijito, 2001). Terdapat dua kebijakan manajemen modal kerja yaitu kebijakan:

\section{a. Kebijakan Investasi}

Vahid et al (2012) melakukan pengukur kebijakan pada kegiatan investasi perusahaan dengan membandingkan total aktiva lancar terhadap total aset. Investasi Pada perusahaan dapat dilakukan pada aktiva lancar dan aset tetap, namun dalam hal ini Vahid et al (2012) menggunakan total aktiva lancar sebagai proxy untuk mengukur kebijakan yang digunakan perusahaan dalam memutuskan kegiatan investasi agresif. Apabila nilai rasio tersebut kurang dari satu menunjukkan kebijakan yang relatif agresif. Berikut merupakan formula dari aggressive investing policy (AIP):

\begin{tabular}{c} 
AIP $=\frac{\text { Total Aktiva Lancar }(\mathrm{TCA})}{\text { Total Aset }(\mathrm{TA})}$ \\
\hline
\end{tabular}

\section{b. Kebijakan Pembiayaan}

Untuk melihat kebijakan pembiayaan Vahid et al (2012) membandingkan antara total kewajiban lancar terhadap total aset perusahaan untuk menilai tingkat kebijakan pembiayaan agresif. Apabila nilai rasio tersebut kurang dari satu maka kebijakan yang diterapkan perusahaan relatif konservatif. Berikut merupakan formula dari aggressive financing policy (AFP):

$\mathrm{AFP}=\underline{\text { Total Kewajiban Lancar }(\mathrm{TCL})}$ Total Aset (TA)

Sumber: Sartono, 2001

\subsubsection{Profitabilitas (ROA)}

Profitabilitas menurut Shapiro (1991) adalah gambaran kemampuan perusahaan untuk menghasilkan laba dengan menggunakan seluruh modal yang dimiliki perusahaan. Syamsuddin (2004) mengatakan bahwa Return on Asset (ROA) merupakan pengukur kemampuan perusahaan yang dilakukan secara keseluruhan untuk menghasilkan keuntungan dengan jumlah keseluruhan aktiva yang tersedia di dalam perusahaan, semakin tinggi rasio ini berarti semakin baik keadaan suatu perusahaan.

$\mathrm{ROA}=\underline{\text { Laba Setelah Pajak }(\mathrm{EBIT})}$ Total Aktiva

Sumber: Brigham dan Houston, 2001

\subsubsection{Nilai Perusahaan (Tobin's Q)}

Menurut Keown (2005) nilai perusahaan merupakan nilai pasar atas surat berharga hutang dan ekuitas perusahaan yang beredar. Harga yang bersedia dibayar oleh calon pembeli diartikan sebagai harga pasar atas perusahaan itu sendiri ( Husnan, 2000). Jika nilai Tobin's Q antara nol sampai dengan satu menunjukkan aset perusahaan dihargai lebih tinggi dari nilai saham perusahan (undervalue) dan jika nilainya lebih dari satu menyiratkan aset perusahaan lebih rendah dari nilai saham perusahaan yang menyiratkan harga saham perusahaan yang dinilai terlalu tinggi.

$\mathrm{Q}=\frac{(\mathrm{EMV})+\text { Nilai buku total hutang }}{(\mathrm{EBV})+\text { Nilai buku total hutang }}$

Sumber: Smithers dan Wright, 2007

\subsection{Kajian Literatur}

Penelitian pada bidang keuangan terutama pada manajemen modal kerja telah dilakukan pada tingkat teoritis dan empiris dengan hasil yang berbeda. Lazaridis dan Tryfonidis (2006) melakukan penelitian pada 131 perusahaan yang terdaftar pada bursa efek Athena untuk menyelidiki hubungan tradisional perusahaan dan manajemen modal kerja terhadap profitabilitas. Hasil menunjukkan hubungan yang signifikan antara profitabilitas perusahaan dan cash conversion cycle (CCC).

Quayyum (2012) melakukan penelitian pada 28 perusahaan dengan empat sektor industi manufaktur yang terdaftar pada Bursa Efek Dharka dengan periode waktu 2005 hingga 2009. Tujuannya adalah untuk menemukan hubungan antara profitabilitas dan modal kerja untuk membantu perusahaan mengoptimalkan tingkat manajemen modal kerja secara efesien dengan menggunakan return on asset (ROA), net profit margin (NPM), receivable collection period ( $\mathrm{RCP})$, inventory turn over period (ITP), payabel deferal period (PDP) dan cash conversion cycle (CCC). Hasil penelitian ini menjelaskan bahwa manajemen modal kerja memiliki hubungan yang signifikan dengan profitabilitas perusahaan di Bangladesh. Diantara semua komponen, cash conversion cycle yang paling signifikan terhadap total modal.

Penelitian yang dilakukan Akoto et al (2013) dilakukan untuk menguji hubungan antara praktik manajemen modal kerja dengan profitabilitas manufaktur yang terdapat di Ghana. Penelitian ini menemukan bahwa adanya hubungan positif antara manajemen modal kerja dan profitabilitas. Qazi et al (2011) melakukan penelitian untuk melihat dampak dari modal kerja pada profitabilitas dengan sekto minyak dan gas serta industri otomotif Pakistan sebagai sampel. Hasil menunjukkan adanya hubungan positif antara profitabilitas dan modal kerja dalam mengelola manajemen siklus kas.

Penelitian yang dilakukan oleh Sitorus dan Irsutami (2012) pada 12 perusahaan properti dan real estate di Indonesia menemukan adanya pengaruh 
manajemen modal kerja terhadap profitabilitas perusahaan. Sundari (2012) melakukan penelitian pada perusahaan farmasi yang listing di Bursa Efek Indonesia pada tahun 2008 hingga 2012 menemukan variabel periode hutang usaha perusahaan Farmasi berpengaruh secara signifikan dan berhubungan positif dengan profitabilitas (ROA) Perusahaan. Hal ini menunjukkan bahwa semakin besar atau lama pembayaran hutang, maka perusahaan bisa saja sengaja memperpanjang lama pembayaran untuk mendapatkan berbagai keuntungan terlebih dahulu.

Rehman (2006) menyelidiki hubungan kemampuan perusahaan dalam mengelola modal kerja dan profitabilitas secara efektif, dengan menggunakan per putaran persediaan harian, rata-rata periode pembayaran dan cash conversion cycle (CCC). Sampel yang digunakan adalah 94 perusahaan di Pakistan, peneliti menemukan adanya hubungan negatif antara komponen modal kerja terhadap profitabilitas perusahaan yang di pengaruhi oleh tingkat cash conversion cycle (CCC).

Nilmawati (2011) melakukan penelitian pengaruh manajemen modal kerja pada kinerja perusahaan yang terdaftar di Bursa Efek Indonesia menemukan bahwa variabel manajemen modal kerja yang diukur dengan menggunakan cash conversional cycle mempunyai mengaruh negatif signifikan terhadap kinerja perusahaan baik dengan menggunakan ukuran pasar (Tobin's Q) maupun dengan ukuran akuntansi Gross operation profit (GOP). Pengaruh negatif ini menunjukkan bahwa jumlah hari yang dibutuhkan untuk membiayai persediaan dan piutang dikurangi dengan jumlah hari pembayaran kepada supplier yang semakin singkat, akan meningkatkan kinerja perusahaan akan meningkatkan kinerja perusahaan.

Horne dan Wachwicz dalam Nazir dan Afza (2009) menyebutkan bahwa kebijakan investasi yang agresif (AIP) akan memiliki pengaruh positif terhadap profitabilitas perusahaan. Dengan kata lain, kebijakan pembiayaan yang agresif (AFP) akan memiliki pengaruh negatif terhadap profitabilitas perusahaan.

Vahid et al (2012) menemukan hasil yang berbeda pada saat melakukan penelitian pada 28 perusahaan yang terdaftar di Bursa Efek Teheran dengan jangka waktu lima tahun untuk menyelidiki dampak dari kebijakan modal kerja investasi agresif (AIP) dan kebijakan modal kerja pembiayaan agresif (AFP) terhadap profitabilitas dan nilai perusahaan. Variabel yang digunakan dalam penelitian adalah kebijakan investasi agresif (AIP), kebijakan pembiayaan agresif (AFP), ROA dan Tobbin's Q. Penelitian ini menemukan bahwa kebijakan pembiayaan agresif dengan menggunakan hutang jangka panjang dan kebijakan investasi agresif dengan menggunakan aktiva lancar memiliki berpengaruh terhadap profitabilitas dan nilai perusahaan.

\subsection{Pengembangan Hipotesis}

Menilai kebijakan investasi pada perusahaan dapat menggunakan aktiva lancar dan aset tetap. Kenaikan investasi pada aktiva lancar mencerminkan perusahaan menggunakan kebijakan agresif, artinya semakin kecil nilai rasio akan mencerminkan perusahaan menggunakan kebijakan investasi agresif. Pembiayaan pada perusahaan dapat dilakukan dengan menggunakan kewajiban jangka panjang dan kewajiban jangka pendek. Pembiayaan menggunakan kewajiban jangka panjang menggambarkan perusahaan menerapkan kebijakan konservatif sedangkan peningkatan penggunaan kewajiban jangka pendek menggambarkan perusahaan menggunakan kebijakan agresif, artinya semakin tinggi nilai rasio akan mencerminkan perusahaan menggunakan pembiayaan agresif.

\subsubsection{Pengaruh Kebijakan Modal Kerja Terhadap Profitabilitas Perusahaan}

Profitabilitas menurut Shapiro (1991) adalah gambaran kemampuan perusahaan untuk menghasilkan laba dengan menggunakan seluruh modal yang dimiliki perusahaan. Kemampuan perusahaan dalam menghasilkan laba dilakukan melalui kebijakan investasi dan pembiayaan perusahaan. Kebijakan investasi agresif (AIP) pada aktiva lancar meliputi kas atau uang tunai yang dapat digunakan untuk membiayai operasional perusahaan. Menurut Van Home dan Watchowicz (2004) jumlah aktiva lancar yang berlebihan pada perusahaan dapat berdampak negatif pada profitabilitas perusahaan, sedangkat tingkat aktiva lancar yang rendah dapat menurunkan likuiditas sehingga perusahaan mengalami kesulitan dalam mempertahankan kegiatan operasional.

Kemampuan memperoleh laba pada perusahaan akan berbanding terbalik pada kemempuan perusahaan dalam memenuhi kewajiban jangka pendek (likuiditas), ini disebabkan likuiditas yang meningkat merupakan biaya dari ketidak mampuan perusahaan memperoleh laba. Ketika perusahaan ingin meningkatkan profitabilitasnya maka perusahaan akan menghadapi turunya likuiditas. Pada penelitian ini penulis belum mencantumkan arah penelitian karena penelitian ini merupakan penelitian yang baru. Berdasarkan penjelasan diatas, maka hipotesis penulis adalah sebagai berikut:

H1a: Kebijakan manajemen modal kerja investasi agresif (AIP) berpengaruh pada profitabilitas perusahaan

H1b: Kebijakan manajemen modal kerja pembiayaan agresif (AFP) berpengaruh pada profitabilitas perusahaan. 


\subsubsection{Pengaruh Kebijakan Manajemen Modal Kerja Terhadap Nilai Perusahaan}

Biaya modal yang dikeluarkan perusahaan akan berbeda antara perusahaan yang menggunakan kebijakan modal konservatif dan perusahaan yang menggunakan kebijakan modal agresif. Pada teori struktur modal telah dijelaskan bahwa modal dapat meningkatkan nilai atau harga saham pada perusahaan, dengan menekan biaya modal yang dikeluarkan oleh perusahaan. Peningkatan nilai atau haga saham akan berbanding lurus terhadap nilai perusahaan. Pada kondisi tertentu perusahaan dapat memenuhi kebutuhan dananya dengan menggunakan sumber - sumber dari dalam perusahaan, namun saat kebutuhan dana meningkat yang disebabkan perkembangan perusahaan, maka perusahaan akan cenderung menggunakan dana yang berasal dari luar perusahaan yang berupa hutang (debt).

Penggunaan hutang pada perusahaan akan menaikkan nilai saham, karena adanya kenaikan pajak yang merupakan pos deduksi terhadap biaya hutang, namun pada titik tertentu penggunaan hutang dapat menurunkan nilai saham karena adanya pengaruh biaya kepailitan dan biaya bunga yang ditimbulkan dari adanya penggunaan hutang (Sawir, 2004). Menurut Sukirni (2012) kebijakan pembiayaan berpengaruh terhadap nilai perusahaan. Hasil penelitian ini tidak sejalan terhadap penelitian Hemastuti (2014), hasil ini menunjukkan bahwa kebijakan pembiayaan secara parsial tidak berpengaruh terhadap nilai perusahaan. Berdasarkan penjelasan diatas, maka hipotesis penulis adalah sebagai berikut:

H2a: Kebijakan manajemen modal kerja investasi agresif (AIP) berpengaruh pada nilai perusahaan.

$\mathrm{H} 2$ b: Kebijakan manajemen modal kerja pembiayaan agresif (AFP) berpengaruh pada nilai perusahaan.

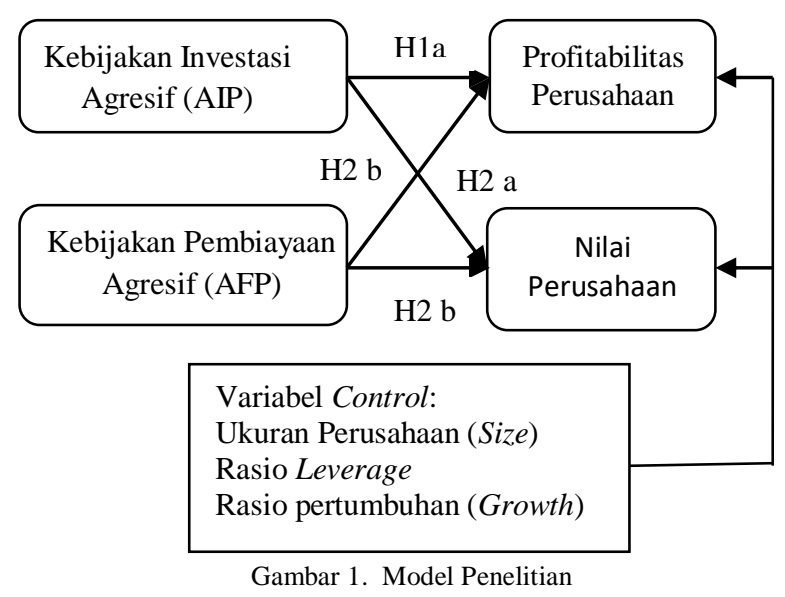

\section{HASIL DAN PEMBAHASAN}

Data yang digunakan dalam penelitian ini adalah perusahaan manufaktur yang terdaftar pada BEI (Bursa Efek Indonesia) selama tahun 2010-2014 sebanyak 131 perusahaan. Jumlah 131 perusahaan tersebut dikurangi dengan kriteria sebagai berikut:

Tabel 1 Sampel Penelitian

\begin{tabular}{|l|c|}
\hline \multicolumn{1}{|c|}{ Kriteria } & Jumlah \\
\hline $\begin{array}{l}\text { Perusahaan manufaktur yang terdaftar di Bursa } \\
\text { Efek Indonesia }\end{array}$ & 131 \\
\hline Mata uang selain rupiah pada laporan keuangan. & (32) \\
\hline Perusahaan dengan nilai buku negatif. & (33) \\
\hline $\begin{array}{l}\text { Perusahaan yang melakukan penggabungan usaha } \\
\text { (Marger) }\end{array}$ & (32) \\
\hline Total sampel penelitian 2010-2014 & 34 \\
\hline
\end{tabular}

Total sampel pada penelitian ini sebanyak 34 perusahaan selama lima tahun yang kemudian dipooling menjadi 170 observasi. Jenis data yang digunakan dalam penelitian ini adalah data sekunder dalam tipe rasio dengan menggunakan teknik pengumpulan arsip dibaris data yang dapat diakses melalui www.idx.co.id. Data yang telah diperoleh kemudian diolah melalui proses tabulasi dan entri dengan menggunakan perhitungan komputasi program EVIEWS versi 8.0 dan program Microsoft Excel..

Analisis data yang digunakan dalam penelitian ini adalah analisis regresi berganda data panel. Untuk mengetahui tingkat signifikansi dari setiap koefisien regresi variabel independen terhadap variabel dependen maka akan digunakan uji statistik, diantaranya adalah:

\subsection{Analisis Statistik Deskriptif}

Analisa ini bertujuan untuk memberikan gambaran mengenai distribusi dan prilaku data sampel (Ghozali, 2006).

Tabel 2. Statistik Deskriptif

\begin{tabular}{|l|c|c|c|c|}
\hline $\begin{array}{l}\text { Nama } \\
\text { Variabel }\end{array}$ & Mean & Maximum & Minimum & Std. Dev \\
\hline AIP & 0.578824 & 0.910740 & 0.133232 & 0.165238 \\
\hline AFP & 0.309433 & 0.829216 & 0.050595 & 0.161681 \\
\hline ROA & 0.1299216 & 0.651897 & 0.000607 & 0.114421 \\
\hline Tobin's Q & 1.283666 & 5.442391 & 0.321492 & 0.928056 \\
\hline SIZE & 2.833951 & 3.309498 & 2.508254 & 1.807188 \\
\hline LEV & 0.909019 & 5.497959 & 0.083992 & 0.915081 \\
\hline GROWTH & 0.154727 & 3.481070 & -0.998855 & 0.340600 \\
\hline
\end{tabular}


Tabel 2 menyajikan nilai mean dari variable AIP sebesar 0.578824 atau sekitar $58 \%$ yang menyiratkan bahwa perusahaan manufaktur Indonesia mengadopsi kebijakan investasi agresif dengan berinvestasi lebih pada aktiva lancar. AFP sendiri memiliki nilai mean sebesar 0,309433 menyiratkan bahwa perusahaan manufaktur Indonesia menggunakan kebijakan pembiayaan agresif sekitar $31 \%$. Hal ini disebebkan penggunaan total hutang jangka panjang lebih kecil dari penggunaan total aktiva atau sama dengan nol(0), dimana untuk terciptanya kebijakan pembiayaan konservatif (AFP) nilai total hutang jangka panjang harus lebih besar dari nol atau sama dengan satu (1).

Nilai rata-rata (Mean) ROA sebeasar 0.1299216 menunjukkan bahwa pada periode 2010 sampai 2014 perusahaan manufaktur di Indonesia memiliki tingkat pertumbuhan profit sebesar $13 \%$ dengan nilai sandar deviasi 0,165238. Standar deviasi yang lebih kecil dari nilai mean menggambarkan sebaran variabel data yang kecil atau tidak adanya kesenjangan yang cukup besar dari rasio ROA untuk nilai minimum dan maximum variabel ROA. Untuk nilai mean Tobin's Q yang lebih besar dari satu ( 1.282666) menggambarkan harga saham perusahaan melebihi nilai buku dan mengindikasikan bahwa prospek perusahaan cukup baik. Nilai Standar deviasi $(0,928056)$ yang lebih kecil dari nilai mean menggambark sebaran variabel data yang kecil atau tidak terjadinya kesenjangan antara nilai minimum maupun nilai maximum pada variabel Tobin's Q.

\subsection{Analisis Regresi Data Panel}

Analisis regresi bertujuan untuk mengukur kekuatan hubungan antara dua variabel atau lebih serta menunjukkan arah hubungan antara variabel independen yang digunakan. Pada data panel terdapat tiga model pendekatan yaitu model randome effek, common effek dan fixed effek yang dapat ditentukan dengan menggunakan uji chow (Chow Test) uji Hausman (Hausman Test), Uji Langrangge Multiplier (LM Test). Pada tabel 3 dapat dilihat bahwa H1a, H1b, H2a, H2b menggunakan model Random Effek karena memiliki nilai Cross- section $\mathrm{F}$ lebih kecil dari 0.05, nilai Cros-section Random lebih besar dari 0.05 dan nilai LM Hitung lebih besar dari 0,05.

Tabel 3 Uji Chow, Hausman dan LM $_{\text {Hitung }}$

\begin{tabular}{|c|c|c|c|c|}
\hline \multirow[b]{2}{*}{ Hipotesis } & \multicolumn{2}{|c|}{ Nilai Probabilitas } & \multirow[b]{2}{*}{$\begin{array}{c}\text { LM } \\
\text { Hitung }\end{array}$} & \multirow[b]{2}{*}{$\begin{array}{c}\text { Keputusan } \\
\text { Model }\end{array}$} \\
\hline & $\begin{array}{c}\text { Cros- } \\
\text { section F }\end{array}$ & $\begin{array}{c}\text { Cros- } \\
\text { section } \\
\text { Random }\end{array}$ & & \\
\hline $\mathrm{H} 1 \mathrm{a}$ & 0.000 & 0.3717 & 133.5968 & $\begin{array}{c}\text { Random } \\
\text { effek }\end{array}$ \\
\hline $\mathrm{H} 1 \mathrm{~b}$ & 0.000 & 0.2921 & 139.1184 & $\begin{array}{c}\text { Random } \\
\text { effek }\end{array}$ \\
\hline
\end{tabular}

\begin{tabular}{|c|c|c|c|c|}
\hline $\mathrm{H} 2 \mathrm{a}$ & 0.000 & 0.3892 & 181.1154 & $\begin{array}{c}\text { Random } \\
\text { effek }\end{array}$ \\
\hline $\mathrm{H} 2 \mathrm{~b}$ & 0.000 & 0.3122 & 195.7703 & $\begin{array}{c}\text { Random } \\
\text { effek }\end{array}$ \\
\hline
\end{tabular}

\subsection{Uji Multikolinearitas}

Setelah mendapatkan model regresi data panel maka selanjutnya dilakukan pengujian asumsi klasik. Terdapat dua pengujian asumsi klasik yang dapat dilakukan pada data panel yaitu pengujian Multikolinieritas dan Heteroskedasitas. Model terbaik dalam penelitian ini adalah Random Effect sehingga uji asumsi klasik heteroskedastisitas tidak perlu dilakukan karena pada model random effect sudah memakai metode GLS (Generalized Least Square) yang merupakan salah satu teknik penyembuhan regresi (Suwardi, 2016).

Salah satu cara mengidentifikasi terjadinya multikolinearitas adalah dengan menghitung koefisien korelasi antar variabel independen. Tabel 4 menunjukkan variabel independen terbebas atau tidak ada multikolinearitas karena nilai koefisien variabel independen tidak lebih dari 0.8 .

Tabel 4 Hasil Uji Multikolinearitas

\begin{tabular}{|c|c|c|c|c|c|}
\hline & AIP & AFP & SIZE & LEV & GROWHT \\
\hline AIP & 1.0000 & 0.0201 & -0.2812 & 0.0068 & -0.0283 \\
\hline AFP & 0.0202 & 1.0000 & 0.0014 & 0.7090 & 0.0131 \\
\hline SIZE & -0.2812 & 0.0014 & 1.0000 & 0.0247 & -0.0077 \\
\hline LEV & 0.0068 & 0.7090 & -0.0247 & 1.0000 & 0.0152 \\
\hline GROWHT & -0.0283 & 0.0131 & -0.0077 & 0.0152 & 1.0000 \\
\hline
\end{tabular}

\subsection{Pengujian Hipotesis dan Analisis Data}

3.4.1 Kebijakan investasi agresif (AIP) terhadap profitabilitas perusahaan

Hasil pengujian hipotesis disajikan pada table. 5 dengan menggunakan model random effek.

Tabel 5 Hasil pengujian pengaruh Kebijakan investasi agresif (AIP) terhadap profitabilitas

ROAit $=\beta 0+\beta 1($ TCA $/$ TA $)$ it $+\beta 2$ Lnsize $) i t+\beta 3$ (sales Growth)it $+\beta 4$ (leverage)it + eiit (H1 a)

\begin{tabular}{|c|c|c|c|}
\hline & Coefficient & t-Statistic & Prob. \\
\hline AIP & 0.210738 & 2.689 .323 & 0.0079 \\
\hline SIZE & 0.016559 & 1.937144 & 0.0544 \\
\hline LEV & -0.014216 & -1.211 .271 & 0.2275 \\
\hline GROWHT & 0.006788 & 0.430116 & 0.6677 \\
\hline Konstanta & -0.450180 & -1.753 .047 & 0.0815 \\
\hline R-squared & \multicolumn{3}{|c|}{0.057371} \\
\hline Adjusted R-squared & \multicolumn{3}{|c}{0.034519} \\
\hline F-statistic & 2.510581 \\
\hline
\end{tabular}




\begin{tabular}{|c|c|}
\hline Sampel (N) & 170 \\
\hline Hasil uji Hausman & Random effect \\
\hline \multicolumn{2}{|c|}{ Signifikan pada level 5\% } \\
\hline
\end{tabular}

Nilai mean ROA (profitabilitas) sebesar 0,450 akan meningkat sebesar 0,210 jika variabel AIP (kebijakan investasi agresif) meningkat satu satuan dengan asumsi variabel lain tetap, kemudian akan meningkat sebesar 0,016 jika variabel size meningkat sebesar satu satuan dengan asumsi besarnya variabel lain tetap, lalu akan meningkat sebesar 0,006 jika variabel growht mengalami peningkatan sebesar satu satua, kemudian akan menurun sebesar 0,014 jika variabel lev mengalami penurunan sebesar satu satuan dengan asumsi variabel lain tetap.

Hasil random effect pada hipotesis (1a) menunjukkan bahwa nilai Adjusted $R$-Square pada penelitian ini sebesar 0.034519 yang artinya profitabilitas dipengaruhi kebijakan investasi agresif (AIP) sebesar $3 \%$ dan sisanya $97 \%$ dijelaskan oleh variabel lain. Untuk nilai Prob $F$ Statistic pada hipotesis (1a) sebesar 2.510581 yang artinya bahwa secara bersama-sama variabel independen tidak berpengaruh terhadap variabel dependen karena $2.510581<0.05$. Nilai probabilitas dari kebijakan investasis agresif (AIP) sebesar 0.0079 nilai tersebut lebih kecil dari nilai $\alpha(0.0079<0.05)$ sehingga dapat disimpulkan bahwa kebijakan investasi agresif (AIP) berpengaruh secara signifikan terhadap profitabilitas perusahaan. Besarnya probabilitas pada variabel kontrol size, leverage dan growth lebih besar dari 0,005 sehingga dapat disimpulkan bahwa variabel kontrol pada penelitian ini tidak memiliki hubungan yang signifikan terhadap profitabilitas perusahaan.

Berdasarkan hasil pengujian hipotesis kebijakan investasi agresif (AIP) terhadap profitabilitas yang diukur melalui ROA, dapat disimpulkan bahwa (H1a) terdukung artinya AIP berpengaruh terhadap profitabilitas perusahaan manufaktur yang terdaftar di Bursa Efek Indonesia. Hasil penelitian ini sejalan pada penelitian yang dilakukan oleh Akoto et al (2013) dan Vahid at al (2012) yang menyatakan bahwa dengan memanfaatkan aktiva lancar secara optimal pada perusahaan akan memiliki hubungan signifikan terhadap profitabilitas.

Kebijakan investasi agresif (AIP) melalui aktiva lancar dapat dilakukan dengan investasi jangka pendek pada surat berharga. Investasi pada surat berharga dapat meningkatkan profitabilitas perusahaan karena dana yang mengganggur pada perusahaan digunakan untuk berinvestasi, yang mana investasi tersebut dapat dengan mudah digunakan saat perusahaan membutuhkan dana.
3.4.2 Kebijakan pembiayaan agresif (AFP) terhadap profitabilitas perusahaan

Hasil pengujian hipotesis disajikan pada table.6 dengan menggunakan model random effek.

Tabel 6 Hasil pengujian pengaruh Kebijakan pembiayaan agresif (AFP) terhadap profitabilitas

\begin{tabular}{|c|c|c|c|}
\hline \multicolumn{4}{|c|}{$\begin{array}{c}\left.\mathbf{R O A}_{\text {it }}=\beta 0_{\text {it }}+\beta 1(\text { TCL } / \text { TA })_{\text {it }}+\beta 2 \text { Lnsize }\right)_{\text {it }} \\
\text { Growth })_{\text {it }}+\beta 4(\text { leverage })_{\text {it }}+\varepsilon i \text { it }\end{array}$} \\
\hline & Coefficient & t-Statistic & Prob. \\
\hline AFP & 0.065590 & 0.765537 & 0.4450 \\
\hline SIZE & 0.010822 & 1.249484 & 0.2133 \\
\hline LEV & -0.017957 & -1.194525 & 0.2340 \\
\hline GROWHT & 0.001693 & 0.056709 & 0.9151 \\
\hline Konstanta & -0.181713 & -0.738385 & 0.4613 \\
\hline R-squared & \multicolumn{3}{|c|}{0.018274} \\
\hline Adjusted R-squared & \multicolumn{3}{|c|}{-0.005525} \\
\hline F-statistic & \multicolumn{3}{|c|}{0.767840} \\
\hline Sampel (N) & \multicolumn{3}{|c|}{170} \\
\hline Hasil uji Hausman & \multicolumn{3}{|c|}{ Random effect } \\
\hline Signi & an pada iev & $15 \%$ & \\
\hline
\end{tabular}

Nilai mean ROA (profitabilitas) sebesar -0181 akan meningkat sebesar 0,065 jika variabel AIP (kebijakan investasi agresif) meningkat satu satuan dengan asumsi variabel lain tetap, kemudian akan meningkat sebesar 0,010 jika variabel size meningkat sebesar satu satuan dengan asumsi besarnya variabel lain tetap, lalu akan meningkat sebesar 0,001 jika variabel growht mengalami peningkatan sebesar satu satua, kemudian akan menurun sebesar 0,017 jika variabel lev mengalami penurunan sebesar satu satuan dengan asumsi variabel lain tetp.

Hasil random effect pada hipotesis (1b) menunjukkan bahwa nilai Adjusted $R$-Square pada penelitian ini sebesar -0.005525 yang artinya profitabilitas dipengaruhi kebijakan investasi agresif (AIP) sebesar $6 \%$ dan sisanya $94 \%$ dijelaskan oleh variabel lain. Untuk nilai Prob $F$ Statistic pada hipotesis (1a) sebesar 0.767840 yang artinya bahwa secara bersama-sama variabel independen tidak berpengaruh terhadap variabel dependen karena $0.767840<0.05$. Nilai probabilitas dari kebijakan pembiayaan agresif (AFP) sebesar 0.4450 nilai tersebut lebih besar dari nilai $\alpha(0.4450<0.05)$ sehingga dapat disimpulkan bahwa kebijakan pembiayaan agresif (AFP) tidak berpengaruh terhadap profitabilitas perusahaan. Besarnya probabilitas pada variabel kontrol size, leverage dan growth lebih besar dari 0,005 sehingga dapat disimpulkan bahwa variabel kontrol pada penelitian ini tidak memiliki hubungan yang signifikan terhadap profitabilitas perusahaan.

Berdasarkan hasil pengujian kebijakan pembiayaan agresif (AFP) terhadap profitabilitas yang diukur dengan menggunakan ROA, dapat disimpulkan bahwa (H1b) tidak terdukung artinya AFP tidak berpengaruh terhadap profitabilitas perusahaan manufaktur yang terdaftar di Bursa Efek Indonesia. 
AFP tidak berpengaruh terhadap profitabilitas dikarenakan perusahaan manufaktur di Indonesia tidak menggunakan kebijakan pembiayaan agresif (AFP) hal ini dapat dilihat pada tabel 4.2 dimana nilai mean dari AFP hanya sebesar 0.309433 yang artinya perusahaan yang menggunakan kebijakan AFP hanya sekitar 31 persen. Hasil penelitian ini tidak sejalan terhadap penelitian yang dilakukan oleh Raheman dan Nasr (2007) yang menyatakan bahwa tingkat profitabilitas perusahan dipengaruhi oleh ukuran dan tingkat pembiayaan perusahaan. Pecking Order theori juga menjelaskan bahwa perusahaan yang memiliki tingkat keuntungan yang lebih tinggi mempunyai tingkat pembiayaan yang lebih kecil, hal ini berarti profitabilitas memiliki pengaruh terhadap pembiayaan perusahaan. Penelitian ini sejalan terhadap penelitian yang dilakukan oleh Nazir dan Afza (2009) yang menyatakan bahwa kebijakan pembiayaan tidak memiliki hubungan terhadap profitabilitas perusahaan.

\subsubsection{Kebijakan investasi agresif (AIP) terhadap nilai} perusahaan

Hasil pengujian hipotesis disajikan pada table.7 dengan menggunakan model random effek. nilai mean Tobin's Q (nilai perusahaan) sebesar 1.776 akan meningkat sebesar 2.180 jika variabel AIP ( kebijakan investasi agresif) meningkat satu satuan dengan asumsi variabel lain tetap, kemudian akan meningkat sebesar 0.066 jika variabel size meningkat sebesar satu satuan dengan asumsi besarnya variabel lain tetap, lalu akan meningkat sebesar 0.030 jika variabel growht mengalami peningkatan sebesar satu satua, kemudian akan menurun sebesar 0,112 jika variabel lev mengalami penurunan sebesar satu satuan dengan asumsi variabel lain tetap.

Tabel 7 Hasil pengujian pengaruh Kebijakan investasi agresif (AIP) terhadap nilai

\begin{tabular}{|c|c|c|c|}
\hline \multicolumn{4}{|c|}{ 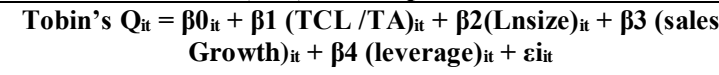 } \\
\hline & Coefficient & t-Statistic & Prob. \\
\hline AIP & 2.180931 & 3.692038 & 0.0003 \\
\hline SIZE & 0.066871 & 0.971126 & 0.3329 \\
\hline LEV & -0.112798 & -1.319111 & 0.1890 \\
\hline GROWHT & 0.030728 & 0.285433 & 0.7757 \\
\hline Konstanta & -1.776011 & -0.865271 & 0.3881 \\
\hline R-squared & \multicolumn{3}{|c|}{0.08123} \\
\hline Adjusted R-squared & \multicolumn{3}{|c|}{0.058957} \\
\hline F-statistic & \multicolumn{3}{|c|}{3.64993} \\
\hline Sampel (N) & \multicolumn{3}{|c|}{170} \\
\hline Hasil uji Hausman & \multicolumn{3}{|c|}{ Random effect } \\
\hline
\end{tabular}

Hasil random effect pada hipotesis (2a) menunjukkan bahwa nilai Adjusted $R$-Square pada penelitian ini sebesar 0.058957 yang artinya profitabilitas dipengaruhi kebijakan investasi agresif (AIP) sebesar $59 \%$ dan sisanya $41 \%$ dijelaskan oleh variabel lain. Untuk nilai Prob F Statistic pada hipotesis (2a) sebesar 3.64993 yang artinya bahwa secara bersama-sama variabel independen tidak berpengaruh terhadap variabel dependen karena $3.64993<0.05$. Nilai probabilitas dari kebijakan investasi agresif (AIP) sebesar 0.0003 nilai tersebut lebih kecil dari nilai $\alpha(0.003<0.05)$ sehingga dapat disimpulkan bahwa kebijakan pembiayaan agresif (AIP) berpengaruh terhadap profitabilitas perusahaan. Besarnya probabilitas pada variabel kontrol size, leverage dan growth lebih besar dari 0,005 sehingga dapat disimpulkan bahwa variabel kontrol pada penelitian ini tidak memiliki hubungan yang signifikan terhadap profitabilitas perusahaan.

Berdasarkan hasil pengujian kebijakan investasi agresif (AIP) terhadap nilai perusahaan dengan menggunakan Tobin's Q dapat disimpulkan bahwa (H2a) terdukung artinya AIP berpengaruh terhadap nilai perusahaan manufaktur yang terdaftar di Bursa Efek Indonesia. Hasil penelitian ini sejalan terhadap penelitian yang dilakukan Permanasari (2010) dan Vahid at al (2012) yang menyatakan bahwa secara langsung maupun tidak langsung, keputusan investasi mempengaruhi nilai perusahaan. Artinya semakin tinggi investasi yang dihasilkan oleh perusahaan, maka nilai perusahaan juga akan meningkat. Peningkatan nilai perusahaan tersebut ditandai dengan meningkatnya penilaian pasar terhadap aktiva perusahaan. Penilaian yang dimaksud adalah seberapa besar pasar akan melakukan appraisal terhadap aset perusahaan. Semakin besar appraisal tersebut, menunjukkan bahwa apabila perusahaan tersebut dijual maka nilainya diatas nilai aset perusahaan itu sendiri. Penilaian itulah yang disebut dengan nilai $\mathrm{Q}$.

3.4.4 Kebijakan pembiayaan agresif (AFP) terhadap nilai perusahaan

Hasil pengujian hipotesis disajikan pada tabel 8 dengan menggunakan model random effek. Nilai mean Tobin's Q (nilai perusahaan) sebesar 0,661 akan menurun sebesar 0,836 jika variabel AIP (kebijakan investasi agresif) menurun satu satuan dengan asumsi variabel lain tetap, kemudian akan meningkat sebesar 0.030 jika variabel size meningkat sebesar satu satuan dengan asumsi besarnya variabel lain tetap, lalu akan menurun sebesar 0.026 jika variabel growht mengalami penurunan sebesar satu satua, kemudian akan meningkat sebesar 0,013 jika variabel LEV mengalami peningkatan sebesar satu satuan dengan asumsi variabel lain tetap.

Tabel 8 Hasil pengujian pengaruh Kebijakan pembiayaan agresif (AIP) terhadap nilai

Tobin's $Q_{i t}=\beta 0+\beta 1(\text { TCA } / \text { TA })_{i t}+\beta 2(\text { Lnsize })_{i t}+\beta 3$ (sales

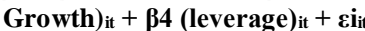




\begin{tabular}{|c|c|c|c|}
\hline & Coefficient & t-Statistic & Prob. \\
\hline AFP & -0.836196 & -1.348 .275 & 0.1794 \\
\hline SIZE & 0.030807 & 0.421589 & 0.6739 \\
\hline LEV & 0.013375 & 0.123197 & 0.9021 \\
\hline GROWHT & -0.026879 & -0.247339 & 0.8050 \\
\hline Konstanta & 0.661358 & 0.318990 & 0.7501 \\
\hline R-squared & 0.015720 \\
\hline Adjusted R-squared & -0.00814 \\
\hline F-statistic & 0.658818 \\
\hline Sampel (N) & \multicolumn{3}{|c|}{170} \\
\hline Hasil uji Hausmandom effec \\
\hline \multicolumn{3}{|c|}{ Signifikan pada level 5\% } \\
\hline
\end{tabular}

Hasil random effect pada hipotesis (2b) menunjukkan bahwa nilai Adjusted $R$-Square pada penelitian ini sebesar -0.00814 yang artinya profitabilitas dipengaruhi kebijakan investasi agresif (AIP) sebesar 0,8\% dan sisanya 99,2\% dijelaskan oleh variabel lain. Untuk nilai Prob F Statistic pada hipotesis (2b) sebesar 0.658818 yang artinya bahwa secara bersama-sama variabel independen tidak berpengaruh terhadap variabel dependen karena $0.658818<0.05$. Nilai probabilitas dari kebijakan pembiayaan agresif (AFP) sebesar 0.1794 nilai tersebut lebih besar dari nilai $\alpha(0.1794<0.05)$ sehingga dapat disimpulkan bahwa kebijakan pembiayaan agresif (AIP) tidak berpengaruh terhadap nilai perusahaan. Besarnya probabilitas pada variabel kontrol size, leverage dan growth lebih besar dari 0,005 sehingga dapat disimpulkan bahwa variabel kontrol pada penelitian ini tidak memiliki hubungan yang signifikan terhadap profitabilitas perusahaan.

Berdasarkan hasil pengujian hipotesis kebijakan pembiayaan agresif (AFP) dapat disimpulkan bahwa $(\mathrm{H} 2 \mathrm{~b})$ tidak terdukung artinya AFP tidak berpengaruh terhadap nilai perusahaan manufaktur yang terdaftar di Bursa Efek Indonesia. AFP tidak berpengaruh terhadap nilai perusahaan dikarenakan perusahaan manufaktur di Indonesia tidak menggunakan kebijakan pembiayaan agresif (AFP) hal ini dapat dilihat pada tabel 4.2 dimana nilai mean dari AFP hanya sebesar 0.309433 yang artinya perusahaan yang menggunakan kebijakan AFP hanya sekitar 31 persen. Hasil penelitian ini sejalan terhadap penelitian yang dilakukan Nazir dan Afza (2009) yang menyatakan bahwa tingkat pembiayaan agresif tidak memiliki hubungan yang signifikan terhadap nilai perusahaan. Hasil penelitian ini tidak sejalan terhadap penelitian yang dilakukan oleh Siaw dan Maggison (2013) yang menyatakan bahwa peningkatan pembiayaan akan menyebabkan penurunan nilai perusahaan. Penambahan pembiayaan akan menyebabkan pasar mengidentifikasi adanya keterbatasan arus kas sehingga perusahaan meningkatan pembiayaan baik jangka pendek maupun jangka panjang.

\subsubsection{Variabel kontrol (Size, Leverage dan Growth)} terhadap profitabilitas dan nilai perusahaan

Variabel Kontrol pada penelitian ini yaitu size, leverage dan sales growth tidak memiliki hubungan yang signifikan terhadap profitabilitas dan nilai perusahaan saat diuji langsung bersama dengan variabel independen. Untuk diuji kembali dengan pendekatan pembagian kelompok selain pembagian langsung juga tidak dapat dilakukan karena sempel pada penelitian ini tidak dapat digolongkan pada kelompok tertentu. Untuk variabel ukuran perusahaan (size) tidak dapat dikelompokkan kedalam ukuran perusahaan kecil, menengah dan besar karena seluruh sampel pada penelitian ini merupakan perusahaan besar dengan kekayaan bersih lebih dari $\mathrm{Rp}$ 10.000.000.000 tidak termasuk tanah dan gedung tempat usaha serta memiliki hasil penjualan tahunan lebih dari Rp 50.000.000.000. Pembagian perusahaan besar, kecil dan menengah ini telah diatur pada UU No. 20 tahun 2008.

Untuk variabel leverage tidak dapat digolongkan pada hutang jangka pendek dan hutang jangka panjang karena menutrut Brigham dan Houston (2010) serta Gibson (1990) pengukur leverage dapat dilakukan dengan membandingkan total hutang terhadap equitas perusahaan. Leverage digunakan untuk mengukur tingkat pengaruh penggunaan hutang terhadap pendapatan saham perusahaan sehingga total hutang tidak dapat dibagi kedalam hutang jangka pendek dan hutang jangka panjang.

Pada variabel sales growth juga tidak dapat dibagi dalam kelompok tertentu karena rasio ini digunakan untuk menggambarkan kemampuan perusahaan dalam mempertahankan posisi ekonomi ditengah laju pertumbuhan ekonomi Indonesia (Kasmir, 2012). Dengan demikian dapat disimpulkan bahwa variabel kontrol pada penelitian ini tidak dapa diuji kembali dengan pendekatan pembagian kelompok tertentu. Penelitian yang dilakukan oleh Vahid et al (2012) pada perusahaan manufaktur di Iran juga tidak melakukan pengujian lebih lanjut pada variabel kontrol size, leverage dan sales growth pada penelitian mereka karena seluruh hipotesis pada penelitian mereka terdukung sedangkan penelitian saat ini (H1b) serta (H2b) tidak terdukung namun tidak dapat dilakukan uji lebih lanjut pada variabel kontrol (size, leverage dan growth) karena perbedaan keadaan perekonomi Iran dan Indonesia.

\section{KESIMPULAN}

Berdasarkan hasil penelitian dan pembahasan kebijakan manajemen modal kerja terhadap profitabilitas dan nilai pada perusahaan manufaktur yang terdaftar di Bursa Efek Indonesia (BEI) tahun 2010 hingga 2014 dapat diambil kesimpulan sebagai berikut: 
Kebijakan manajemen modal kerja investasi agresif (AIP) berpengaruh terhadap profitabilitas perusahaan, ini berarti semakin besar tingkat persentase dari investasi agresif pada perusahaan maka tingkat profitabilitas yang diperoleh perusahaan juga akan semakin besar. Kebijakan manajemen modal kerja pembiayaan agresif (AFP) tidak berpengaruh terhadap profitabilitas perusahaan, ini berarti naik turunya persentasi penggunaan kebijakan pembiayaan agresif (AFP) pada perusahaan tidak akan mempengaruhi profitabilitas yang akan diperoleh perusahaan.

Kebijakan manajemen modal kerja investasi agresif (AIP) berpengaruh terhadap nilai perusahaan, ini berarti semakin besarnya tingkat persentase dari investasi agresif akan meningkatkan nilai pada perusahaan. Kebijakan manajemen modal kerja pembiayaan agresif (AFP) tidak berpengaruh pada nilai perusahaan, artinya naik atau turunya pebiayaan agresif (AFP) tidak akan mempengaruhi nilai perusahaan.

Adapun keterbatasan pada penelitian ini adalah sebagai berikut: Pertama, kebijakan investasi dan pembiayaan hanya diukur berdasarkan sifat agresif tanpa menghiraukan sifat konservatif dari kebijakan investasi dan pembiayaan. Kedua, sampel yang digunakan hanya 34 perusahaan manufaktur dalam periode waktu 2010 hingga 2014.

Berdasarkan hasil penelitian yang telah dilakukan oleh peneliti, maka saran yang dapat diberikan adalah sebagai berikut: Pertama, pengukuran kebijakan manajemen modal investasi dan pembiayaan agresif disarankan untuk ditambah dengan kebijakan manajemen modal kerja investasi dan pembiayaan konservatif. Kedua, memperbanyak data penelitian. Implikasi pada penelitian ini adalah kebijakan manajemen modal kerja pembiayaan agresif mampu meningkatkan profitabilitas dan nilai yang akan diperoleh perusahaa denagan memanfaatkan aktiva lancar secara optimal.

\section{DAFTAR REFERENSI}

[1] Agnes Sawir. (2004). Kebijakan Pendanaan dan Restrukturisasi Perusahaan. Jakarta: Gramedia Pustaka Utama.

[2] Akoto, R, Vitory, D, \& Angmor. (2013). Working capital management and profitability. academicjournal, 373-380.

[3] Anthony, Robert, N., \& Govindaraja, V. (2005). Management Cotrol System (Sistem Pengendalian Manajemen) Buku 1. Jakarta: Salemba Empat.

[4] Brigham, \& Daves. (2010). Intermediate Financial Management 10 th. Sout western: cengage learning.

[5] Brigham, Eugene. F \& Joel. Houston. (2010). Manajemen Keuangan edisi kedelapan. Jakarta: Erlangga.
[6] Deloof. M. (2003). Does Working Capital Management After Profitability of Belgia Firm. Journal of business finance and accounting, Vol 30.

[7] Donald R. Cooper. Pamela S Sclindler. (2006). Metode Riset Bisnis Volum 2. Jakarta: PT Media Global Edukasi

[8] Ferdiansyah. M. S \& Isnuhardi. (2013). Faktor- faktor yang mempengaruhi struktur modal pada perusahaan pertambangan yang terdaftar di busa efek indonesia.

[9] Ghozali, I. (2006). Aplikasi Analisis Multivariate dengan Program SPSS. Semarang: Badan Penerbit Universitas Diponegoro.

[10] Gibson, R, S. (2010). Principles of nutritional assesment. New York: Oxford University.

[11] Gill. Amarjit, Biger. Nahum, Mathur, Nerl. (2010). Relation Ship Betwen Working Capital Management and Profitability: Evidence from Unite Startes. Business and economics Journal vol 2010,1-9

[12] Gitosudarmo, \& Indriyo. (1992). Manajemen Keuangan edisi 3. Yogyakarta: BPFE Yogyakarta.

[13] Gujarati,Damondar. (2012). Dasar-dasar Ekonometrika terjemahan Mangungsong buku dua edisi lima. Jakarta: salemba empat.

[14] Horne, James, C. John, M. (2001). Fundamental of Financial Management. Singapore: Prentice Hall.

[15] Kasmir. (2012). Analisa Laporan Keuangan. Jakarta: Rajawali Pers

[16] Keown. (2005). Dasar- dasar managemen keuangan. Jakarta: PT. Raja Gafindo Persada.

[17] Kurama, \& Saputra. (2014). Pengaruh Efesiensi Modal Kerja Pada Profitabilitas. E- Jurnal Akuntansi Universitas Udayana, 340355.

[18] Lazaridis, I. D, Triforidis. (2006). Relation Ship Betwen Working Capital Management and Profitability of Listed Companies in Athens Stock Exchange. Journal of Financial Management and Analisis. 19(1), 23-23.

[19] Martono, \& Harjito, A. (2010). Manajemen Keuangan edisi 3. Yogyakarta: Ekonis.

[20] Munawir, S. (2004). Analisa Laporan Keuangan. Yogyakarta: Erlangga

[21] Myers S.C, \& Majluf.N.S. (1984). Corporate Financing and Investment decision when firms have information that investor do not have. Journal of Financial Economics 13 , 187-221.

[22] Nachowi. Hardius. Usman. (2006). Pendekatan popular dan praktis ekonomika untuk analisis ekonomi dan keuangan: Fakultas ekonomi universitas indonesia

[23] Nilmawati. (2011). pengaruh manajemen modal kerja pada kinerja perusahaan yang terdaftar di BEI. Karisma" Universitas Pembangunan Nasional Veteram Yogyakarta" , 129-140.

[24] Qazi, H. a., shan, s. m., abbas, z., \& nadem, t. (2011). Impact Of Working Capital on Firms Profitability. African Journal of Business Management.

[25] Quayyum, S. T. (2012). Relationship betwen working capital management and profitability in context of manufacturing industries in Bangladesh. International Journal of Businness and Management vol 7 . 
[26]Riyanto, B. (2008). Dasar pembelajaran Akuntansi. Yogyakarta: BPFE Yogyakarta.

[27] Riyanto, B. (1995). Dasar-Dasar Pembelajaran Perusahaan edisi 4. Yogyakarta: BPFE.

[28] Sitorus, \& Irsutami. (2012). Analisa Pengaruh Manajemen Modal Kerja Terhadap Profitabilitas.

[29] Sartono. Agus. (2001). Manajemen keuangan teori dan aplikasi edisi 4. Yogyakarta: BPFE

[30] Shapiro, \& Alan.C. (1991). Modern Corporate Finance. New York: Macmilan Publishing Company.

[31] Sugiarto. (2009). Struktur modal, struktur kepemilikan perusahaan, permasalahaan keagenan dan informasi asimetri. Yogyakarta: Graha ilmu.

[32] Sundari, C. N. (2012). Pengaruh Manajemen Modal Kerja Terhadap Profitabilitas Perusahaan.

[33] Suwardi, A. (2016, Mei 16). Data Panel Teori Dasar dan Aplikasi. Diambil kembali dari Academia:

https://www.academia.edu/7967973/DATA_PANEL_TEORI_DAS

AR_DAN_APLIKASI_DI_STATA_Oleh_Akbar_Suwardi
[34]Syamsuddin. Lukman. (2007). Manajemen Keuangan Perusahaan: Konsep Aplikasi dalam Perencanaan, Pengawasan, dan Pengambilan Keputusan. Jakarta: PT. Raja Grafindo Persada.

[35]Vahid, T. K., Mohsen, A. K., \& Mohammadreza, E. (2012). The Impact of Working capital Manajement Policies on Firm's Profitability and value: Efidence from Iranian Companies. Internatoinal Reserch Journal Of Financial and Economics , 155162.

[36]Wahidati. (2002). Pengaruh Kepemilikan Manajerial dan Kepemilikan Institusional. Jurnal Riset Akuntansi Indonesia Vol 5 , 1-16.

[37]Wibison, Yusuf. (2005). Metode Statistika. Yogyakarta: Gajahmada University Perss.

[38]Widarjono, Agus. (2006). Ekonometrika untuk analisis ekonomi dan keuangan. Jakarta: UI.

[39]http://www.bi.go.id/id/tentang-bi/uubi/Documents/ UU20Tahun 2008UMKM.pdf 